Article

\title{
Characteristics, Composition and Oxidative Stability of Lannea microcarpa Seed and Seed Oil
}

\author{
Patrice Bazongo ${ }^{1}$, Imaël Henri Nestor Bassolé ${ }^{1, *}$, Søren Nielsen ${ }^{2}$, Adama Hilou ${ }^{3}$, \\ Mamoudou Hama Dicko ${ }^{1}$ and Vijai K. S. Shukla ${ }^{2}$
}

1 Laboratoire de Biochimie Alimentaire, Enzymologie, Biotechnologie Industrielle et Bioinformatique (Laboratoire BAEBIB), Department of Biochemistry and Microbiology, Université de Ouagadougou, Ouagadougou 0303 BP 7021, Burkina Faso;

E-Mails: pathcobaz@yahoo.fr (P.B.); mdicko@univ-ouaga.bf (M.H.D.)

2 International Food Science Centre (IFSC A/S), Sønderskovvej, Lystrup 7 DK-8520, Denmark; E-Mails: sn@ifsc.dk (S.N.); gamma1948@hotmail.com (V.K.S.S.)

3 Laboratoire de Biochimie et Chimie Appliquées (LABIOCA), UFR/SVT, Université de Ouagadougou, Ouagadougou 0909 BP 848, Burkina Faso; E-Mail: hiloudio@gmail.com

* Author to whom correspondence should be addressed; E-Mail: hbassole@hotmail.com; Tel.: +226-7812-5004.

Received: 13 November 2013; in revised form: 6 December 2013 / Accepted: 9 December 2013 / Published: 24 February 2014

\begin{abstract}
The proximate composition of seeds and main physicochemical properties and thermal stability of oil extracted from Lannea microcarpa seeds were evaluated. The percentage composition of the seeds was: ash (3.11\%), crude oil $(64.90 \%)$, protein $(21.14 \%)$, total carbohydrate $(10.85 \%)$ and moisture (3.24\%). Physicochemical properties of the oil were: refractive index, 1.473 ; melting point, $22.60^{\circ} \mathrm{C}$; saponification value, $194.23 \mathrm{mg}$ of $\mathrm{KOH} / \mathrm{g}$ of oil; iodine value, $61.33 \mathrm{~g}$ of $\mathrm{I}_{2} / 100 \mathrm{~g}$ of oil; acid value, $1.21 \mathrm{mg}$ of $\mathrm{KOH} / \mathrm{g}$ of oil; peroxide value, 1.48 meq of $\mathrm{O}_{2} / \mathrm{kg}$ of oil and oxidative stability index, $43.20 \mathrm{~h}$. Oleic $(43.45 \%)$, palmitic $(34.45 \%)$, linoleic $(11.20 \%)$ and stearic $(8.35 \%)$ acids were the most dominant fatty acids. Triacylglycerols with equivalent carbon number (ECN) 48 and ECN 46 were dominant (46.96\% and 37.31\%, respectively). The major triacylglycerol constituents were palmitoyl diolein (POO) (21.23\%), followed by dipalmitoyl olein (POP) (16.47\%), palmitoyl linoleyl olein (PLO) (12.03\%), dipalmitoyl linolein (PLP) (10.85\%) and dioleoyl linolein (LOO) (9.30\%). The total polyphenol and tocopherol contents were $1.39 \mathrm{mg} \mathrm{GAE} \mathrm{g}^{-1}$ DW and $578.56 \mathrm{ppm}$, respectively. $\gamma$-Tocopherol was the major tocopherol (437.23 ppm).
\end{abstract}


These analytical results indicated that the L. microcarpa seed oil could be used as a frying oil and in the cosmetic industry.

Keywords: Lannea microcarpa; seed oil; oxidative stability; fatty acids; triacylglycerols; phenolic compounds

\section{Introduction}

Recent studies have shown that some seeds might have useful applications in animal feeds, based on their nutritional values, and as raw materials for paint formulations, based on the amount and nature of their constituent oils [1]. Thus, scientists of various specialties have invested effort to highlight these new products and their industrial applications, such as for cooking, pharmaceutical, or cosmetic purposes.

Anarcadiaceae family species are well represented in Africa and have sizes between range between those of trees and small shrubs. The genus Lannea belongs to the Anacardiaceae family and comprises about 40 species which are restricted to Africa [2].

Lannea microcarpa, commonly known as African grape, is widely distributed in the sub-Saharan region from Senegal to Cameroon. Traditional remedies prepared from its leaves, bark, roots and fruits are used to treat mouth blisters, rheumatism, sore throats, dysentery, conjunctivitis, stomatitis, skin eruptions, and ulcers [2,3]. The fruit is eaten raw or dried, and a number of fermented or soft drinks are produced from its juice. Important concentrations of phenolic compounds with strong antioxidant capacities have been found in the fruit $(1005.75 \mathrm{mg} / 100 \mathrm{~g}$ of fruit) [4]. 4'-methoxymyricetin 3-O- $\alpha$-Lrhamnopyranoside, myricetin 3-O- $\alpha$-L-rhamnopyranoside, myricetin 3-O- $\beta$-D-glucopyranoside, vitexin, isovitexin, gallic acid, and epicatechin have been identified as major constituents of the leaf extracts [3]. Partial reports are available on its seed and seed oil protein and lipid contents and their compositions [5], however, literature reports concerning the detailed lipid, triacylglycerol and phenolic compounds composition and oil stability are rather lacking. This study was therefore conducted to document the characteristics, composition and oxidative stability of L. microcarpa seeds and seed oil in order to determine their potential to be commercially exploited for industrial applications.

\section{Results and Discussion}

\subsection{Proximate Composition of Seeds}

The proximate composition of L. microcarpa seeds is shown in Table 1 . The seeds contained 3.24\% of moisture, $3.11 \%$ of ash, $10.85 \%$ of total carbohydrates, $21.14 \%$ of crude protein and $64.90 \%$ of crude oil. The crude oil and protein contents were lower and higher respectively than those previously reported by Glew et al. [5]. The seeds can be considered as a good source of oil and protein. The moisture content was beneficial for prolonging the shelf life of the seeds. 
Table 1. Proximate composition of Lannea microcarpa seeds (g/100 g dry weight basis).

\begin{tabular}{ll}
\hline Components & Contents \\
\hline Moisture (\%) & $3.24 \pm 0.56$ \\
Proteins & $21.14 \pm 0.25$ \\
Lipids & $64.90 \pm 1.27$ \\
Carbohydrates & $10.85 \pm 1.56$ \\
Ash & $3.11 \pm 0.22$ \\
\hline
\end{tabular}

Mean $\pm \mathrm{SD}, n=3$.

\subsection{The Physicochemical Properties of Seed Oil}

Physicochemical properties of L. microcarpa seed oil are listed in Table 2. The oil exhibited refractive index of 1.473 which was similar to that of Acacia senegal seed oil [6]. The seed oil melting point was $22.60{ }^{\circ} \mathrm{C}$ which makes it a liquid at ambient temperature. The saponification value, $194.23 \mathrm{mg} \mathrm{KOH} / \mathrm{g}$ of oil, was lower than that reported for lauric oil (240-265 KOH/g of oil) and in the range of those of cotton seed oil (193-195) and linseed oil (193-195) [6,7]. Triacyglycerols containing short-chain fatty acids have higher saponification values than those with longer chain fatty acids [8]. The L. microcarpa seed oil was rich in $\mathrm{C}_{16}$ and $\mathrm{C}_{18}$ acids which explained its relatively low saponification value. The low iodine value of $61.33 / 100 \mathrm{~g}$ of oil was due to its low unsaturated fatty acid contents. The oil can be classified as a non-drying oil. The acid and peroxide values were $1.21 \mathrm{mg}$ of $\mathrm{KOH} / \mathrm{g}$ of oil and $1.48 \mathrm{meq}$ of $\mathrm{O}_{2} / \mathrm{kg}$ of oil, respectively. These low values suggest that the oil can be stored for a long period without deterioration [9].

Table 2. Physicochemical properties of Lannea microcarpa seed oil.

\begin{tabular}{ll}
\hline Physicochemical properties & Value \\
\hline Refractive index $\left(25^{\circ} \mathrm{C}\right)$ & $1.473 \pm 001$ \\
Melting point $\left({ }^{\circ} \mathrm{C}\right)$ & $22.60 \pm 0.75$ \\
Saponification value $(\mathrm{mg}$ of $\mathrm{KOH} / \mathrm{g}$ of oil) & $194.23 \pm 0.80$ \\
Iodine value $\left(\mathrm{g}\right.$ of $\mathrm{I}_{2} / 100 \mathrm{~g}$ of oil) & $61.33 \pm 0.25$ \\
Acid value $(\mathrm{mg}$ of $\mathrm{KOH} / \mathrm{g}$ of oil) & $1.21 \pm 0.01$ \\
Peroxide value (meq of $\mathrm{O}_{2} / \mathrm{kg}$ of oil) & $1.48 \pm 0.11$ \\
Oxidative stability index $(\mathrm{h})$ & $43.20 \pm 2.00$ \\
\hline
\end{tabular}

Mean $\pm \mathrm{SD}, n=3$.

The stability of L. microcarpa seed oil at $130{ }^{\circ} \mathrm{C}$ expressed as the oxidation induction time was $43.20 \mathrm{~h}$. This value was higher than those of $6.10 \mathrm{~h}$ and $1.10 \mathrm{~h}$ determined at $120{ }^{\circ} \mathrm{C}$ for olive and linseed oils, respectively [10]. The high oxidation induction time confirms high oxidative stability of L. microcarpa seed oil. Due to its high oxidative stability of the L. microcarpa seed oil can be used as edible cooking or frying oil.

\subsection{Fatty Acid Composition}

The fatty acid composition of crude oil of L. microcarpa seeds is presented in Table 3 . A total of 10 fatty acids were identified. The most abundant fatty acids were oleic (44.05\%), palmitic (34.45\%), linoleic (11.20\%) and stearic (8.35\%) acids which accounted for $98.05 \%$ of the total fatty acids. The 
saturated, monounsaturated and polyunsaturated fatty acids were $44.10 \%, 44.35 \%$ and $11.55 \%$ of the total fatty acids, respectively. The fatty acid composition of L. microcarpa seed oil was comparable to that of Adansonia digitata seed oil [11] and like that one, the L. microcarpa seed oil can be regarded as a oleic-palmitic oil while that reported by Glew et al. [5] was a palmitic-linoleic-oleic type oil. The variations in fatty acid composition, lipid and protein contents may be attributed to the seed maturity, climatic conditions, growth location, and interactions between these factors. Oleic and palmitic acids have been reported to be effective percutaneous absorption enhancers [12,13]. In addition, microcarpa seed oil had relative high content in linoleic acid which is the most frequently used fatty acid in cosmetic products as it moisturises the skin, aids in the healing process of dermatoses and sunburns [14]. In recent years, baobab oil has been added to the list of fixed oils commonly included in cosmetic products due to its high contents in palmitic and oleic acids [11]. Like baobab oil, the L. microcarpa seed oil thus has a good cosmetic potential.

Table 3. Fatty acid composition of Lannea microcarpa seed oil.

\begin{tabular}{ll}
\hline Fatty acid & Values \\
\hline Palmitic acid 16:0 & $34.45 \pm 0.35$ \\
Heptadecanoic acid 17:0 & $0.20 \pm 0.00$ \\
Stearic acid 18:0 & $8.35 \pm 0.21$ \\
Oleic acid 18:1 $\mathrm{n}-9$ & $43.45 \pm 0.21$ \\
Oleic acid 18:1 Trans & $0.6 \pm 0.05$ \\
Linoleic acid 18:2 $\mathrm{n}-6$ & $11.20 \pm 0.13$ \\
Linolenic 18:3 $\mathrm{n}-3$ & $0.35 \pm 0.07$ \\
Eicosanoic acid 20:0 & $0.9 \pm 0.03$ \\
Eicosenoic acid 20:1 $\mathrm{n}-9$ & $0.3 \pm 0.01$ \\
Behenic acid 22:0 & $0.2 \pm 0.01$ \\
SFA & 44.10 \\
MUFA & 44.35 \\
PUFA & 11.55 \\
\hline
\end{tabular}

SFA, saturated fatty acid; MUFA: monounsaturated fatty acid, PUFA: polyunsaturated fatty acid, (mean $\pm \mathrm{SD}, n=2$ ).

\subsection{Triacylglycerol (TAG) Profile}

Table 4 shows the triacylglycerol composition of $L$. microcarpa seed oil. According to the results, the oil contained five triacylglycerol types [from equivalent carbon number (ECN) 44 to ECN 52]. Triacylglycerols with ECN 48 were dominant (46. 96\%), followed by TAGs ECN 46 (37.31\%), TAGs ECN 50 (10.21\%), TAGs ECN 44 (4.01\%) and TAGs ECN 52 (1.51\%). Major TAG constituents were palmitoyl diolein (POO) (21.23\%), followed by dipalmitoyl olein (POP) (16.47\%), palmitoyl linoleyl olein (PLO) (12.03\%), dipalmitoyl linolein (PLP) (10.85\%) and dioleoyl linolein (LOO) (9.30\%). The saturated fatty acids were absent from the sn-2 position and the major TAG molecular species had oleic and linoleic acids at the sn-2 position. This result reflects the high unsaturation of the oil. Good agreement between the fatty acid and TAG compositions was also found. 
Table 4. Triglyceride composition (Mole \%) of Lannea microcarpa seed oil.

\begin{tabular}{lll}
\hline Triglyceride & ECN & Values \\
\hline POP & 48 & $16.47 \pm 0.09$ \\
POS & 50 & $6.51 \pm 0.01$ \\
SOS & 52 & $1.51 \pm 0.02$ \\
PLP & 46 & $10.85 \pm 0.07$ \\
POO & 48 & $21.23 \pm 0.53$ \\
SOO & 50 & $3.7 \pm 0.14$ \\
LLO & 44 & $2.50 \pm 0.03$ \\
PLL & 46 & $5.13 \pm 0.32$ \\
PLnO & 44 & $1.51 \pm 0.02$ \\
LOO & 46 & $9.30 \pm 0.00$ \\
PLO & 46 & $12.03 \pm 0.25$ \\
OOO & 48 & $6.24 \pm 0.34$ \\
SLO & 48 & $3.02 \pm 0.03$ \\
\hline
\end{tabular}

POP: dipalmitoyl olein; POS: palmitoyl oleoyl stearin; SOS: distearoyl olein; PLP: dipalmitoyl linolein; POO: palmitoyl diolein; SOO: stearoyl diolein; LLO: dilinoleyol olein; PLL: palmitoyl dilinolein; PLnO: palmitoyl linolenoyl olein; LOO: linoleyol diolein; PLO: palmitoyl linoleyl olein, OOO: triolein; SLO: stearoyl linoleyl olein (mean $\pm \mathrm{SD}, n=2$ ).

\subsection{Phenolic Compound Contents}

The total polyphenol content of L. microcarpa seed oil was $1.39 \mathrm{mg}$ gallic acid equivalent (GAE) $\mathrm{g}^{-1}$ dry weight (DW). This value is higher than those of $0.067-1.295 \mathrm{mg} / \mathrm{g}$ of oil reported for olive oil [15]. The tocopherol composition of L. microcarpa seed oil is given in Table 5. The most frequent form of tocopherol was $\gamma$-tocopherol (437.23 ppm), followed by $\alpha$-tocopherol $(89.40 \mathrm{ppm})$ and $\delta$-tocopherol (51.93 ppm). $\beta$-Tocopherol was not detected. Total amount of tocopherol (578.56 ppm) in L. microcarpa seed oil was higher than that recorded in Sclerocarya birrea seed oil (137 ppm) and olive oil (100-300 ppm) [16,17].

Table 5. Total polyphenol content and tocopherol Composition of Lannea microcarpa seed oil.

\begin{tabular}{ll}
\hline Components & Values \\
\hline Total polyphenol (mg GAE g $\left.{ }^{-1} \mathrm{DW}\right)$ & $1.39 \pm 0.05$ \\
$\alpha$-tocopherol $(\mathrm{ppm})$ & $89.40 \pm 0.57$ \\
$\beta$-tocopherol $(\mathrm{ppm})$ & $0.00 \pm 0.00$ \\
$\gamma$-tocopherol $(\mathrm{ppm})$ & $437.23 \pm 1.73$ \\
$\delta$-tocopherol $(\mathrm{ppm})$ & $51.93 \pm 0.11$ \\
Total tocopherol (ppm) & $578.56 \pm 2.19$ \\
\hline
\end{tabular}

Mean $\pm \mathrm{SD}, n=2$.

The high oxidative stability of $L$. microcarpa can be due to its polyphenol and tocopherol contents. Gutierrez et al. [18] observed that removal of polyphenol from olive without altering other antioxidant components lead to the loss of 50\% of the oil stability. Huang et al. [19] have reported the contribution of tocopherol to corn oil stability. The antioxidant activity of tocopherol in oils is greatly dependent on its composition. The same author noted that at $100 \mathrm{ppm}, \alpha$-tocopherol exerted the best antioxidant 
activity in corn oil when compared with $\gamma$-tocopherol and $\delta$-tocopherol. Baldioli et al. [20] reported the synergistic effect of $\alpha$-tocopherol with hydrophilic phenols on the oxidative stability in virgin olive oils.

\section{Experimental Section}

\subsection{Plant Material}

Fruits of L. microcarpa $(1.5 \mathrm{~kg})$ at the same maturity stage were collected on ground at Djanga (latitude $10.37 \mathrm{~N}$; longitude $4.47 \mathrm{~W}$ ) and Bérégadougou (latitude $10.49 \mathrm{~N}$; longitude $4.47 \mathrm{~W}$ ) villages in the Southwest of Burkina Faso. Before their transport to the laboratory, the fruits were hand sorted to eliminate damaged ones. Prior to any analysis, fruit samples were washed with glass-distilled water, drained, and air dried under laboratory conditions $\left(22-23{ }^{\circ} \mathrm{C}\right)$ for one week. The dried seeds were milled with a Moulinex grinder (GT550, Zurich, Switzerland) then sieved using a $1 \mathrm{~mm}$ mesh sieve and stored at $-18{ }^{\circ} \mathrm{C}$ until analyses.

\subsection{Seed Analysis}

Moisture, protein, ash and lipid contents were determined according to the protocols established by the Association of Official Analytical Chemists [21]. Moisture was determined gravimetrically after drying the sample overnight at $105{ }^{\circ} \mathrm{C}$. Total protein content $(\%$ total nitrogen $\times 6.25)$ was established by the Kjeldahl method. Ash was quantified after incinerating the sample overnight at $550{ }^{\circ} \mathrm{C}$. Total lipids were determined by Soxhlet extraction with petroleum ether for $6 \mathrm{~h}$, after which the solvent was removed using a rotary vacuum evaporator. Carbohydrate content (on dry weight basis) was estimated by difference of mean values: 100 - (sum of percentages of ash, protein and lipids) [22].

\subsection{Physicochemical Analysis of the Oil}

Official methods of the American Oil Chemists' Society were used for the determination of saponification (Cd 3-25), iodine (Cd 1-25), peroxide ( $\mathrm{Cd} \mathrm{8-53)} \mathrm{and} \mathrm{acid} \mathrm{(Ca} \mathrm{3a-63)} \mathrm{values} \mathrm{[23].}$ Refractive index was measured at $25{ }^{\circ} \mathrm{C}$ with an Abbe refractometer (Atago 2T, Tokyo, Japan). The oxidative stability index (OSI) was evaluated using Rancimat method. Stability was measured with a 743 rancimat instrument (Metrohm, Herisau, Switzerland) using an oil sample of $3 \mathrm{~g}$, warmed to $130{ }^{\circ} \mathrm{C}$ and an air flow rate of $20 \mathrm{~L} / \mathrm{h}$. Stability was expressed as induction time (h). All the analyses were carried out in triplicate and the results are expressed as the mean \pm standard deviation $(x \pm S D)$.

\subsection{Fatty Acid Analysis}

The oil was transesterified with boron trifluoride and gas liquid chromatography (GLC) of fatty acid methyl esters were performed using a Perkin Elmer 8500 system fitted with a programmable temperature vaporizer (PTV) injector and a flame ionization detector (FID) with a data processor [24]. Helium was used as carrier gas. The column temperature was initially maintained at $175^{\circ} \mathrm{C}$ and then raised by $1{ }^{\circ} \mathrm{C} / \mathrm{min}$ to $200{ }^{\circ} \mathrm{C}$ held for $10 \mathrm{~min}$ and then raised by $2{ }^{\circ} \mathrm{C} / \mathrm{min}$ to $230{ }^{\circ} \mathrm{C}$ and held for $20 \mathrm{~min}$. The PTV injector was initially maintained at $45^{\circ} \mathrm{C}$ and immediately after the injection raised to $250{ }^{\circ} \mathrm{C}$. The FID was kept at $300{ }^{\circ} \mathrm{C}$. The capillary column $(30.0 \mathrm{~m} \times 0.25 \mathrm{~mm})$ employed was $\mathrm{CP}$ 
Sil 88 (Chrompack/Varian Instruments, Walnut Creek, CA, USA) with a film thickness at $0.2 \mu \mathrm{m}$. The peaks were identified by comparing retention times with authentic fatty acid methyl esters. This experiment was carried out in duplicate.

\subsection{Triglyceride Composition Analysis}

Triglyceride compositions were determined according to method describe by Shukla et al. [25]. The HPLC system consisted of a Spectra Physics (SP 8000) chromatograph (Spectra-Physics, Santa Clara, CA, USA), coupled with a Pye Unicam LC-UV detector (Pye Unicam Ltd., Cambridge, UK) at $220 \mathrm{~nm}$, and a Rheodyne loop (5 $\mu \mathrm{L}$ ) injector (model 7125, Rheodyne, Cotati, CA, USA). A model 9800 differential refractometer (Knauer, Berlin, Germany)was used for refractive index measurements. An SP 8000 electronic integrator was used to obtain accurate retention times at a chart speed of $0.25 \mathrm{~cm} / \mathrm{min}$. The columns used for the separations consisted of two $150 \mathrm{~mm} \times 4.5 \mathrm{~mm}$ I.D. Spherisorb S3 ODS 2 (Phase Separations, Clwyd, UK) arranged in series and packed with $3 \mu \mathrm{m} \mathrm{C}_{18}$ bonded phase particles. The columns were maintained at $20{ }^{\circ} \mathrm{C}$ by coupling the column oven with a Hetofrig cooling system (type 03 PF 623 CB 11, Birkerod, Denmark). The mobile phase consisted of acetonitriletetrahydrofuran (70:30 v/v), both of HPLC grade (Rathburn, Walkerburn, U.K.), and the flow rate was $1.0 \mathrm{~mL} / \mathrm{min}$. The sample size was $5-10 \mu \mathrm{L}$ of ca. $10 \%$ solutions of triglycerides. Triglyceride isomers were identified by comparison of their retention time to those of cocoa butter obtained under similar analytical conditions [24]. The analysis was done in duplicate.

\subsection{Determination of Total Polyphenol Content (TPC)}

TPC in the oil was evaluated using the Folin-Ciocalteu assay, as adapted by Gharibzahedi et al. [26], with some modifications. Distilled water $(3.16 \mathrm{~mL})$ was mixed with a DMSO solution of the oil $(40 \mu \mathrm{L})$ and then Folin Ciocalteu reagent $(200 \mu \mathrm{L})$ was added to the solution. This mixture was allowed to stand at room temperature for $5 \mathrm{~min}$ and then $600 \mu$ Lof $20 \%$ sodium carbonate solution was added. After $2 \mathrm{~h}$ of incubation, the absorbances were measured at $765 \mathrm{~nm}$ using a UV-visible spectrophotometer (Epoch, Biotek, Winooski, VT, USA). Results were expressed as mg GAE per g of oil. This experiment was performed in duplicate.

\subsection{Tocopherol Analysis}

Tocopherols were separated and quantified by HPLC, according to AOCS method Ce 8-89 [23]. Oil was dissolved in $n$-hexane and submitted directly to HPLC analysis. A Perkin Elmer Fluorescence detector Series 200 and a Rheodyne 7125 Injector (IDEX Health and Science, Oak Harbor, WA, USA) equipped with a $20 \mu \mathrm{L}$ loop were used. Excitation wavelength was $290 \mathrm{~nm}$ and Emission wavelength was $330 \mathrm{~nm}$. The solvent system used was water saturated hexane, hexane and propan-2-ol (49.55:49.55:0.9). The columns consisted of $2 \times 150 \mathrm{~mm} 4.6 \mathrm{~mm}$ I.D. packed with $3 \mu \mathrm{m} \mathrm{CN}$ particles [27]. A mixed tocopherols standard was used, which contained $\alpha-, \beta-, \gamma-, \delta$-tocopherols (Sigma-Aldrich, Inc., St. Louis, MO, USA). The tocopherol contents of samples were quantified by the external standard method. The analysis was done in duplicate. 


\section{Conclusions}

In this study, the composition and physicochemical characteristics of L. microcarpa seed and seed oil from Burkina Faso were evaluated. Seeds were characterized by high crude oil and good protein contents that make them valuable as animal feed or for human nutrition. High oxidative stability of the oil due to its polyphenol and tocopherol contents was comparable to those of Moringa pterygosperma, Sclerocarya birrea seed and Olea europaea fruit oils. The obtained data suggest that the L. microcarpa seed oil has a good potential as a frying oil and can be used in the cosmetic industry.

\section{Acknowledgments}

We thank Danish International Development Agency, DANIDA, for financially supporting these studies and AnneMette Lykke for her untiring efforts in coordinating the whole project (Qualitree.neri.dk) [28].

\section{Conflicts of Interest}

The authors declare no conflict of interest.

\section{References}

1. Ajavi, I.A. Comparative study of the chemical composition and mineral element content of Artocarpus heterophyllus and Treculia africana seed and seed oils. Bioresour. Technol. 2008, 99, 5125-5129.

2. Marquet, M.; Jansen, P.C.M. Lannea microcarpa Engl. and K. Krause. In Prota 3: Dyes and Tannins/Colorants et Tanins; Jansen, P.C.M., Cardon, D., Eds.; Prota: Wageningen, The Netherlands, 2005.

3. Picerno, P.; Mencherini, T.; Loggia, R.D.; Meloni, M.; Sanogo, R.; Aquino, R.P. An extract of Lannea microcarpa: composition, activity and evaluation of cutaneous irritation in cell cultures and reconstituted human epidermis. J. Pharm. Pharmacol. 2006, 58, 981-988.

4. Lamien-Meda, A.; Lamien, C.E.; Compaoré, M.M.Y.; Meda, R.N.T.; Kiendrebeogo, M.; Zeba, B.; Millogo, J.F.; Nacoulma, O.G. Polyphenol content and antioxidant activity of fourteen wild edible fruits from Burkina Faso. Molecules 2008, 13, 581-594.

5. Glew, R.H.; VanderJagt, D.J.; Lockett, C.; Grivetti, L.E.; Smith, G.C.; Pastuszyn, A.J.; Millson, M. Amino acid, fatty acid, and mineral composition of 24 indigenous plants of Burkina Faso. J. Food Comp. Anal. 1997, 10, 205-217.

6. Nehdi, I.A.; Sbihi, H.; Tan, C.P.; Zarrouk, H.; Khalil, M.I.; Al-Resayes, S.I. Characteristics, composition and thermal stability of Acacia senegal (L.) Willd. seed oil. Ind. Crops Prod. 2012, $36,54-58$.

7. Pearson, D. The Chemical Analysis of Foods, 8th ed.; Churchill Livingstone: Edinburgh, UK, 1981.

8. O'Brien, R.D. Fats and Oils: Formulations and Processing for Application, 3rd ed.; CRC Press: Boca Raton, FL, USA, 2009; pp. 197-260. 
9. Ojeh, O. Effects of refining on the physical and chemical properties of cashew kernel oil. Int. J. Food Sci. Technol. 1981, 16, 513-517.

10. Wagner, K.-H.; Elmadf, I. Effects of tocopherols and their mixtures on the oxidative stability of olive oil and linseed oil under heating. Eur. J. Lipid Sci. Technol. 2000, 102, 624-629.

11. Vermaak, I.; Kamatou, G.P.P.; Komane-Mofokeng, B.; Viljoen, A.M.; Beckett, K. African seed oils of commercial importance-Cosmetic applications. S. Afr. J. Bot. 2011, 77, 920-933.

12. Larrucea, E.; Arellano, A.; Santoyo, S.; Ygartua, P. Combined effects of oleic acid and propylene glycol on the percutaneous penetration of tenoxicam and its retention in the skin. Eur. J. Pharm. Biopharm. 2001, 52, 113-119.

13. Kim, M.J.; Doh, H.J.; Choi, M.K.; Chung, S.J.; Shim, C.K.; Kim, D.D.; Kim, J.S.; Yong, C.S.; Choi, H.G. Skin permeation enhancement of diclofenac by fatty acids. Drug Del. 2008, 15, 373-379.

14. Lautenschläger, H. Essential fatty acids—cosmetic from inside and outside. Beauty Forum 2003, 4, 54-56.

15. Beltrán, G.; Ruano, M.T.; Jiménez, A.; Uceda, M.; Aguilera, M.P. Evaluation of virgin olive oil bitterness by total phenol content analysis. Eur. J. Lipid Sci. Technol. 2007, 108, 193-197.

16. Fedeli, E.; Cortesi, N. Qualità, provenienza e tecnologia degli oli di oliva vergini. Riv. Ital. Sostanze. Gr. 1993, 70, 419-426.

17. Mariod, A.; Matthaus, B.; Eichner, K. Fatty acid, tocopherol and sterol composition as well as oxidative stability of three unusual Sudanese oils. J. Food Lipids 2004, 11, 179-189.

18. Gutierrez, F.; Arnaud, T.; Garrido, A. Contribution of polyphenols to the oxidative stability of virgin olive oil. J. Sci. Food Agric. 2001, 81, 1463-1470.

19. Huang, S.-W.; Frankel, E.N.; German, J.B. Antioxidant activity of $\alpha$ - and $\gamma$-tocopherols in bulk oils and in oil-in-water emulsions. J. Agric. Food Chem. 1994, 42, 2108-2114.

20. Baldioli, M.; Srvili, M.; Perretti, G.; Montedoro, G.F. Antioxidant activity of tocopherols and phenolic compounds of virgin olive oil. J. Am. Oil Chem. Soc. 1996, 73, 1589-1593.

21. Association of Official Analytical Chemists (AOAC). Official Methods of Analysis of AOAC International, 16th ed; AOAC International: Washington, DC, USA, 1999.

22. Al-Hooti, S.; Sidhu, J.S.; Qabazard, H. Chemical composition of seeds date fruit cultivars of United Arab Emirates. J. Food Sci. Technol. 1988, 35, 44-46.

23. American Oil Chemists' Society (AOCS). Official Methods and Recommended Practices of the American Oil Chemists' Society, 4th ed.; AOCS Press: Champaign, IL, USA, 1990.

24. International Union of Pure and Applied Chemistry (IUPAC). Standards Methods for Analysis of Oils, Fats and Derivatives, 6th ed.; Pergamon Press: Oxford, UK, 1979.

25. Shukla, V.K.S.; Nielsen, W.S.; Batsberg, W. A simple and direct procedure for the evaluation of triglyceride composition of cocoa butters by high performance liquid chromatography-a comparison with the existing TLC-GC method. Eur. J. Lipid Sci. Tech. 1983, 85, 274-278.

26. Gharibzahedi, S.M.T.; Mousavi, S.M.; Hamedi, M.; Rezaei, K.; Khodaiyan, F. Evaluation of physicochemical properties and antioxidant activities of Persian walnut oil obtained by several extraction methods. Ind. Crops Prod. 2013, 45, 133-140. 
27. Shukla, V.K.S.; Jensen, O.H. Fatty acid composition and tocopherol content of amazonian palm oils. J. Food Lipids 1996, 3, 149-154.

28. QualiTree (research-based tree oil production in West Africa). Available online: http://www.qualitree.neri.dk/ (accessed on 13 November 2013).

Sample Availability: Samples of the seed oil of Lannea microcarpa are available from the authors.

(C) 2014 by the authors; licensee MDPI, Basel, Switzerland. This article is an open access article distributed under the terms and conditions of the Creative Commons Attribution license (http://creativecommons.org/licenses/by/3.0/). 